\title{
青海省同德县乔木状甘蒙柽柳的年龄及其生长对 环境的响应
}

\author{
方欧娅 $1^{*} \quad$ 贾恒锋 $^{2}$ 邱红岩 ${ }^{1}$ 任海保 ${ }^{1}$ \\ ${ }^{1}$ 中国科学院植物研究所植被与环境变化国家重点实验室, 北京 $100093{ }^{2}$ 三峡大学生物与制药学院, 湖北宜昌 443002
}

\begin{abstract}
摘 要 青海省同德县高原河漫滩地区存在乔木状的甘蒙柽柳(Tamarix austromongolica), 且在即将修建的水电站库区成林 分布, 引发了学者和公众在其是否属于古树而需要保护以及如何保护问题上的广泛关注。该研究利用树木年轮学方法, 调查 了水库淹没区和非淹没区中胸径较大的甘蒙柽柳的树龄, 分析了甘蒙柽柳的生长历史及其对环境因素的响应。研究发现胸径 较大的甘蒙柽柳可由多株合生形成, 测量胸径与植株个体年龄之间无直接联系。该地区甘蒙柽柳径向生长量在20世纪70-80 年代迅速提升, 80年代后生长趋于平稳。甘蒙柽柳的径向生长响应于7、8月份的水分条件, 径流的增加在一定程度上促进了 甘蒙柽柳的生长。未成熟植株的径向生长与生长季的风速有着显著的负相关关系。研究结果对甘蒙柽柳特殊形态的形成认知 具有理论意义，对该树种保护方案的评估具有实践意义。
\end{abstract}

关键词 甘蒙柽柳; 乔木状; 树轮; 径流; 风速

引用格式: 方欧娅, 贾恒锋, 邱红岩, 任海保 (2017). 青海省同德县乔木状甘蒙柽柳的年龄及其生长对环境的响应. 植物生态学报, 41, 738-748. doi: 10.17521/cjpe.2017.0088

\section{Age of arboreous Tamarix austromongolica and its growth response to environment in Tongde County of Qinghai, China}

FANG Ou-Ya ${ }^{1 *}$, JIA Heng-Feng ${ }^{2}$, QIU Hong-Yan ${ }^{1}$, and REN Hai-Bao ${ }^{1}$

${ }^{1}$ State Key Laboratory of Vegetation and Environmental Change, Institute of Botany, the Chinese Academy of Sciences, Beijing 100093, China; and ${ }^{2}$ College of Biology and Pharmacy, China Three Gorges University, Yichang, Hubei 443002, China

\begin{abstract}
Aims The objectives were to identify the age of the arboreous Tamarix austromongolica in the flood plain area of the Qinghai Plateau and clarify the response patterns of T. austromongolica's growth to the environmental factors. We focused on social issues about whether the T. austromongolica should be protected and how to protect in the reservoir area of a hydropower station.

Methods In this study, arboreous T. austromongolica in both reservoir submerged and non-submerged areas were sampled and measured based on the dendrochronology method. The ages were estimated based on the geometrical characteristics of the pith and the identified age of the inner ring. The correlation and response analysis showed the relationship between $T$. austromongolica's growth and environmental factors.

Important findings We accurately determined the age and historical growth dynamics of the T. austromongolica with large diameter at breast height $(D B H)$. The results showed a special accretion phenomenon in arboreous $T$. austromongolica, which accelerated the $D B H$ increasing, i.e. no direct relationship existed between the plants' $D B H$ and ages of the individuals. Radial growth of T. austromongolica, increased rapidly in the 1970s and 1980s and began to stabilize in the late 1980s, and mainly responded to the runoff in July and August of the Yellow River. Increasing runoff would promote the radial growth of $T$. austromongolica. The growth of the immaturate plant showed significant negative correlation with the wind speed in the growing season. The results will be of theoretical significance to the formation of the special morphology of the T. austromongolica, and will provide scientific practical guidance in designing the protection schemes.
\end{abstract}

Key words Tamarix austromongolica; arboreous; tree ring; runoff; wind speed

Citation: Fang OY, Jia HF, Qiu HY, Ren HB (2017). Age of arboreous Tamarix austromongolica and its growth response to environment in Tongde County of Qinghai, China. Chinese Journal of Plant Ecology, 41, 738-748. doi: 10.17521/cjpe.2017.0088

收稿日期Received: 2017-04-02 接受日期Accepted: 2017-06-16

* E-mail: oyfang@ibcas.ac.cn 
在青海省同德县巴沟乡然果村黄河岸边海拔 约 $2660 \mathrm{~m}$ 的河漫滩沙地上, 存在约 $10 \mathrm{hm}^{2}$ 乔木状且 具较大树干胸径的甘蒙柽柳(Tamarix austromongolica) 林, 位于即将建设的羊曲水电站水利工程淹没 区。这片甘蒙柽柳林是否存在古树而应当被保护, 以及如何实施保护, 受到了学者和公众的广泛关注, 且引起了极大的争议(吴玉虎, 2012; 新华社, 2016; 中国周刊, 2016), 从而直接影响了水利工程的进程 和生态保护工程的开展。我们以水利工程即将淹没 地带的然果村甘蒙柽柳林为主要研究区, 结合以工 程淹没区外的班多村甘蒙柽柳林为辅助研究区, 针 对社会关注问题开展了树木年轮学研究, 旨在回答 以下两个重点问题: 1) 甘蒙柽柳林中是否存在年龄 较大的古树; 2)该地区甘蒙柽柳特殊的乔木状形态 是如何形成的, 甘蒙柽柳生长历史及其与环境条件 的关系是怎样的?

树木年轮学在历史定年(邵雪梅等, 2007; Li et al., 2015)以及树木生长对环境响应的评估(Babst et al., 2013; Gou et al., 2015; Zhang et al., 2015)等方面有 着突出的贡献。树木的生长受到环境因素的限制作 用, 其长期的轮宽变化与气候、环境变化之间存在 一定的相关关系(Li et al., 2016; Yin et al., 2016), 从 而使得树木的径向生长对气候、环境等因素具有较 为明确的响应(Fang et al., 2016; Qin et al., 2016; Wang et al., 2017)。明确这种响应关系有助于评估气 候变化、环境变迁对树木生长的影响(Rohner et al., 2016; Gao et al., 2017), 为未来气候变化或者人为 改变(如移植等)的植物生境条件下的植物生长评估 提供依据。

目前针对柽柳属(Tamarix)植被的研究对象通常 为幼龄树, 成熟甘蒙柽柳分枝结构复杂, 干形较差 而较难开展相关研究(Brotherson et al., 1984; 肖生 春等, 2005; Xia et al., 2016)。以柽柳属植物为研究 对象的树木年轮学工作主要集中在树轮水文学方面, 附近河流湖泊或地下水的水位变化与柽柳生长通常 具有显著关系(肖生春等, 2004; Xiao et al., 2014), 从而使得在气候变化影响下, 柽柳生长状况、森林 群落结构发生改变(Horton \& Clark, 2001)。另一方面, 柽柳对水分条件的响应有助于分析历史时期水文条 件变化(Xiao et al., 2016)。由于柽柳独特的生长环境, 其埋藏亚化石样本可以应用于古环境的探究(Lipp et al., 1996; Yang et al., 1996; Frumkin, 2009)。以柽
柳为对象的树木年轮学研究在多个学科中具有一定 的应用价值, 如研究者利用柽柳年轮对堆积物的响 应, 判断河漫滩沉积年, 沙丘形成演化, 从而进行 地貌学相关研究(Friedman et al., 2005; Birken \& Cooper, 2006; Wang et al., 2010; 张锦春等, 2014)。 基于前期科研工作者的成果, 我们提出假设, 认为 位于高原河漫滩的甘蒙柽柳的生长同样也响应于河 流水文条件等环境因子的变化。然而, 针对近年来 发现的研究区特殊形态的甘蒙柽柳, 其历史生长过 程及环境响应关系尚未见报道。

本研究以青海省同德县乔木状甘蒙柽柳为对 象, 调查胸径较大的植株年龄, 分析甘蒙柽柳径向 生长与流域径流等环境要素的关系。对该甘蒙柽柳 林大树年龄的准确判断是评估其生态价值所亟待解 决的重要问题, 同时, 甘蒙柽柳的生长对环境的响 应也是评估其在移植环境下生长状况的重要依据。

\section{1 数据和方法}

\section{1 研究区概况}

研究区属于秦岭地槽褶皱系的青海南山冒地 槽带, 断裂构造发育。黄河对高原面不断侵蚀, 形成 阶地和较为宽大的河谷, 并在河流弯曲凸岸形成河 漫滩。河漫滩以石砾质冲积土和沙质冲积土为主, 土层较厚, 土壤发育程度差。在此之上分布有少量 耐旱耐水抗风且耐碱土的植被, 典型的有甘蒙柽柳 和小叶杨(Populus simonii)。该区域为温带大陆性干 旱气候, 常年低温干旱, 据兴海气象站1981-2010年 数据统计, 全年平均气温 $1.7{ }^{\circ} \mathrm{C}$, 最暖月在 7 月, 平 均气温 $12.7^{\circ} \mathrm{C}$, 最冷月在 1 月, 平均气温 $-11.0^{\circ} \mathrm{C}$ 。降 水稀少, 且主要集中在5-9月, 最大降水量出现在7 月, 平均7月降水总量约 $86.6 \mathrm{~mm}$, 年降水总量约为 $377.8 \mathrm{~mm}$ 。2-4月为该地大风发生频率最高的季节, 受到山地地形的影响, 东西向山谷风偏大。

本研究主要针对羊曲水电站淹没区然果村甘 蒙柽柳林(35.54 $4^{\circ} \mathrm{N}, 100.16^{\circ} \mathrm{E}$, 海拔2 $678 \mathrm{~m}$ )开展研 究, 同时也涉及了库区附近非淹没区班多村甘蒙柽 柳林地(35.33 $\mathrm{N}, 100.26^{\circ} \mathrm{E}$, 海拔2 $730 \mathrm{~m}$ )(图1)。然 果村林地甘蒙柽柳种群呈斑块状分布, 径级呈现较 强的正偏态和尖顶分布特征, 胸径集中分布在20-30 $\mathrm{cm}$ 。林地具有大量胸径超过 $30 \mathrm{~cm}$ 的植株, 其中测量 胸径值最大为 $132.1 \mathrm{~cm}$, 该植株被媒体称为“柽柳 王”。胸径 $20 \mathrm{~cm}$ 以上的植株平均树高约为 $8 \mathrm{~m}$ 。班多 


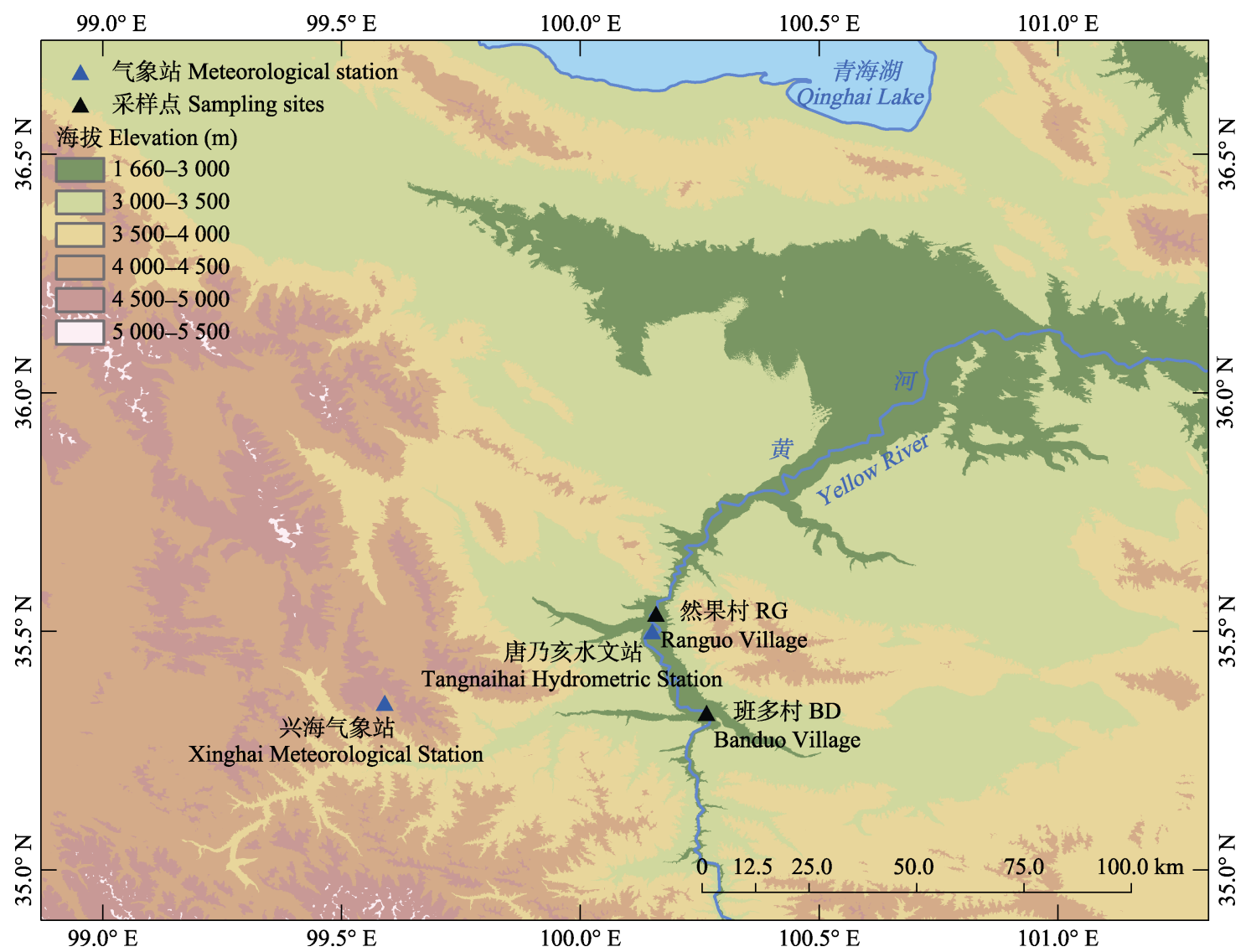

图1 青海同德县甘蒙柽柳采样点。

Fig. 1 Sampling sites of Tamarix austromongolica in Tongde, Qinghai.

村林地甘蒙柽柳种群径级呈对称、常峰态分布, 较 然果村具有更多的胸径超过 $30 \mathrm{~cm}$ 的植株, 然而超过 $50 \mathrm{~cm}$ 的植株在该区域十分罕见。两地甘蒙柽柳平均 胸径和树高无显著差异, 且林下均缺乏幼苗更新。

\section{2 树轮样本采集及测量}

我们于2016年11月下旬赴青海省同德县开展了 实地调查, 利用直径 $5.15 \mathrm{~mm}$ 的生长锥着重针对胸 径较大的甘蒙柽柳进行采样并同时对其胸径进行测 量。在然果村以及班多村分别采集了 37 株和 15 株活 立木的树芯样本, 同时分别获取了 4 株和 1 株倒木圆 盘样本(表1)。针对个别胸径较大且疑似多株合生树 木获取多根样芯, 如“柽柳王” (编号RG-X05), 我们 进行了 5 个方向的树芯采集。由于然果村甘蒙柽柳林 普遍受到泥石流等灾害的影响, 树木个体存在损伤, 采样时尽量避免树木损伤部位, 对较为明确的坚直 干材进行样本采集。依照同样的方法, 在班多村进 行了树轮样本的采集。取样中, 尽量钻取到树木髓 心位置或者能够在树芯上显示出树轮圆弧的近树木 髓心位置, 为后续的树龄准确判断提供依据。

在实验室, 将树芯样本固定后连同圆盘样本用
砂纸进行精细打磨, 直至在显微镜下能够清晰显示 木质部细胞。继而利用Lintab 6树轮宽度测量仪 (Rinntech, Heidelberg, Germany)对所有样本的树轮 宽度进行测量, 测量精度为 $0.001 \mathrm{~mm}$ 。

\section{3 定年及建立年表}

采样时间2016年11月甘蒙柽柳当年生长已完成, 树皮内部木质部最外轮判断为2016年生长, 依此对 树轮进行初步定年。对比研究区所有样本的树轮宽 度变化, 结合骨架图和 COFECHA程序 (Holmes, 1983)进行准确的交叉定年, 从而判断树轮样本年 轮的确切形成年份。在对甘蒙柽柳历史生长状况进 行初步了解后, 通过负指数函数或直线拟合并去除 其生长趋势, 建立标准化树轮年表。

\section{4 树龄判断}

具有髓心的树木均以最内轮年份为树木年龄 的判断依据, 部分样芯采集时获取到近髓心位置的 圆弧形特征, 我们依据其几何结构判断最内轮距离 髓心长度从而估算树木的实际年龄(Norton et al., 1987)。圆盘样本均具有髓心, 经过交叉定年判断倒 伏年份, 获取实际树龄值。需要说明的是, 这里所述 
表1 同德县甘蒙柽柳采样树木年龄

Table 1 Ages of sampling Tamarix austromongolica in Tongde County

\begin{tabular}{|c|c|c|c|c|c|c|c|}
\hline 样本号 Sample ID & 胸径 $D B H(\mathrm{~cm})$ & 年龄1) $\mathrm{Age}^{1)}$ & $\begin{array}{l}\text { 最小年龄2) } \\
\text { Minimum age }^{2)}\end{array}$ & 样本号 Sample ID & 胸径 $D B H(\mathrm{~cm})$ & 年龄1) Age $^{1)}$ & $\begin{array}{l}\text { 最小年龄 } \\
\text { Minimum age }^{2)}\end{array}$ \\
\hline RG-X01 & 23.2 & 28 & & RG-X27 & 28.0 & 25 & \\
\hline RG-X02 & 24.8 & 36 & & RG-X28 & 20.4 & 23 & \\
\hline RG-X03 & 28.6 & & 34 & RG-X29 & 22.6 & 22 & \\
\hline RG-X04 & 31.2 & 35 & & RG-X30 & 21.3 & 19 & \\
\hline RG-X05A & 132.1 & 86 & & RG-X31 & 21.6 & 15 & \\
\hline RG-X05B & 132.1 & 42 & $39^{3)}$ & RG-X32A & 33.7 & & 19 \\
\hline RG-X05C & 132.1 & 31 & & RG-X33 & 19.2 & 22 & \\
\hline RG-X05D & 132.1 & 64 & & RG-X34 & 25.5 & 23 & \\
\hline RG-X05E & 132.1 & 35 & & RG-X35 & 29.6 & & \\
\hline RG-X06A & 105.0 & 18 & & RG-X36 & 36.3 & 28 & \\
\hline RG-X06B & 105.0 & 35 & & RG-X37 & 49.7 & & 40 \\
\hline RG-X07 & 51.3 & & 40 & RG-P38 & 19.7 & 30 & \\
\hline RG-X08 & 31.5 & & 48 & RG-P39 & 18.5 & 27 & \\
\hline RG-X09A & 37.9 & & 28 & RG-P40 & 18.1 & 39 & \\
\hline RG-X10 & 35.7 & 32 & & RG-P41 & 57.6 & 115 & \\
\hline RG-X11A & 104.4 & & 19 & BD-X01A & 42.3 & 28 & \\
\hline RG-X12A & 98.4 & & 39 & BD-X02 & 28.0 & & 24 \\
\hline RG-X13A & 69.7 & 58 & & BD-X03 & 29.3 & 23 & \\
\hline RG-X14A & 63.0 & 32 & & BD-X04 & 17.2 & & 20 \\
\hline RG-X15A & 107.3 & & 86 & BD-X05 & 33.1 & 52 & \\
\hline RG-X16 & 58.3 & 86 & & BD-X06A & 89.4 & 40 & \\
\hline RG-X17 & 43.6 & & 29 & BD-X07A & 63.0 & 41 & \\
\hline RG-X18 & 38.2 & & 78 & BD-X08A & 39.5 & & 41 \\
\hline RG-X19 & 49.3 & & 23 & BD-X09A & 65.1 & & 39 \\
\hline RG-X20 & 37.9 & & 20 & BD-X10 & 45.8 & 46 & \\
\hline RG-X21 & 42.7 & 33 & & BD-X11 & 30.9 & 54 & \\
\hline RG-X22 & 28.3 & 22 & & BD-X12 & 37.6 & 46 & \\
\hline RG-X23 & 26.7 & 21 & & BD-X13 & 22.6 & 52 & \\
\hline RG-X24A & 111.7 & & 34 & BD-X14 & 29.0 & 56 & \\
\hline RG-X25A & 59.2 & & 24 & BD-X15 & 32.8 & & 45 \\
\hline RG-X26 & 25.5 & & 24 & BD-P16 & 19.4 & 38 & \\
\hline
\end{tabular}

BD, 班多村样本; RG, 然果村样本。P, 圆盘; X, 样芯。样本编号中的数字表示不同植株, 数字后字母表示多株合生树之分株。1), 显示髓心的树轮样本 年龄; 2), 未显示髓心的树轮样本最内轮年龄; 3), 该树芯样本包含不同株的两段, 其中内段样本未显示髓心。

$\mathrm{DBH}$, diameter at breast height. BD, the specimen from Banduo Village; RG, the specimen from Ranguo Village. P, disc; X, core. Division of the plant is identified by a letter accompanying the number which refer to the plant number in the Sample IDs. 1), Ages identified by the samples with trunk pith; 2), Ages identified by the samples without trunk pith, which just show the first year of the samples; 3 ), The specimen includes two fragments, of which the inner part does not show the pith.

的实际树龄均为树干处年龄，植株生长到采样高度 年份为生长起始年。在树芯样本中存在22株22根样 芯上不存在髓心圆弧特征, 无法准确获知树木年龄, 仅记录样芯最内轮年份, 判断其最小年龄。

\section{5 相关及响应分析}

为了探究甘蒙柽柳径向生长与气候、环境要素 之间的相关及响应关系, 本研究将树轮标准年表与 气候环境因子月值数据集的数据关系进行分析。所
涉及的气候数据包括唐乃亥水文站1956-2007年黄 河年径流系列统计以及兴海气象站1960-2015年月 平均温度、降水、风速数据集。相关及响应分析均 利用Dendro 2002软件(Biondi \& Waikul, 2004)完成, 其中响应分析采用自举法随机执行 500 次。由于前一 年环境因子对树木当年生长有着一定的作用，故而 研究选用前一年生长季末至当年生长季末的月值数 据进行分析。 


\section{2 结果}

\section{1 甘蒙柽柳的年龄及多株合生现象}

在 52 株活立木的 57 根树芯样本中, 有 8 株 9 根树 芯样本具有树木髓心部分, 该类样本经过交叉定年 即可获取树木的实际年龄值。样芯中, 24 株树的 26 根树芯最内侧树轮显示出有接近髓心的圆弧形特征, 间接获取其树木的年龄值。5个圆盘样本均获取准确 年龄。结果表明, 最大年龄115年, 源于一株倒木圆 盘样本RG-P41, 另外, RG-X15A样本未采集到近髓 心部位, 然而实测样本最内轮形成年份已达公元 1931年，立木实际年龄可能接近或超过100年。

研究着重对然果村“柽柳王” (实测胸径132.1 cm) 进行了树龄分析, 5 个位置取样分析的结果显示, 每 个树芯样本在距树皮12-22 cm处显示了各自的髓 心。交叉定年工作发现各树芯的年龄具有较大差异, 最小年龄为31年, 最大年龄为86年, 证明了该“柽柳 王”的确为多株合生。此外, 该多株合生的植株其中 一根样芯中包含2段树芯样本, 每段样本经交叉定 年发现它们具有同时生长的时段, 故而进一步判断 该甘蒙柽柳为至少包含 2 层的多株合生植株。

\section{2 甘蒙柽柳生长动态}

1960年以前, 样本量较小, 年表受到个体特征 影响较大。20世纪70年代, 甘蒙柽柳生长逐渐加快, 且综合同期同地区甘蒙柽柳区域每木检尺工作，甘 蒙柽柳林植株年龄集中分布在20-40年之间, 即在
该时期存在大量新生个体。20世纪 80 年代初以来, 甘蒙柽柳径向生长趋于稳定。

研究区甘蒙柽柳年径向生长量个体间差异较 大，在取样树木样本中，树木平均年生长速率在 $1.8 \mathrm{~mm} \cdot \mathrm{a}^{-1}$ 至 $8.3 \mathrm{~mm} \cdot \mathrm{a}^{-1}$ 之间。然果村与班多村的树 木历史生长过程没有显著差异, 两地的树轮宽度年 表(图2)显示, 高频及低频趋势均基本吻合。其中, 班多村极端低值波动幅度略小, 表现出更为稳定的 生长动态。

两地年表均显示在 20世纪70年代甘蒙柽柳径 向生长多次出现极低值, 并在1988年、1992年、1995 年、2002年、2008年以及2015年同时具有极低值，该 时期或年份甘蒙柽柳的径向生长量较低。

\section{3 甘蒙柽柳径向生长对环境的响应}

同德县甘蒙柽柳的径向生长主要与黄河径流 流量以及风速存在较为显著的相关性。甘蒙柽柳径 向生长与7、8月黄河径流流量之间存在正相关关系, 显著与7月径流正相关及响应关系 $(p<0.05)$ 体现在 班多村研究区(图3), 在然果村则与8月的径流量间 的相关性更强(图4)。

甘蒙柽柳径向生长与风速之间的显著负相关 主要发生在植被生长季, 在班多村, 甘蒙柽柳生长 与当年 4-8月的风速之间存在显著的负相关 $(p<$ $0.05)$, 明确的显著负响应发生在当年的5-6月(图3)。 而在然果村, 甘蒙柽柳径向生长与风速之间的显著

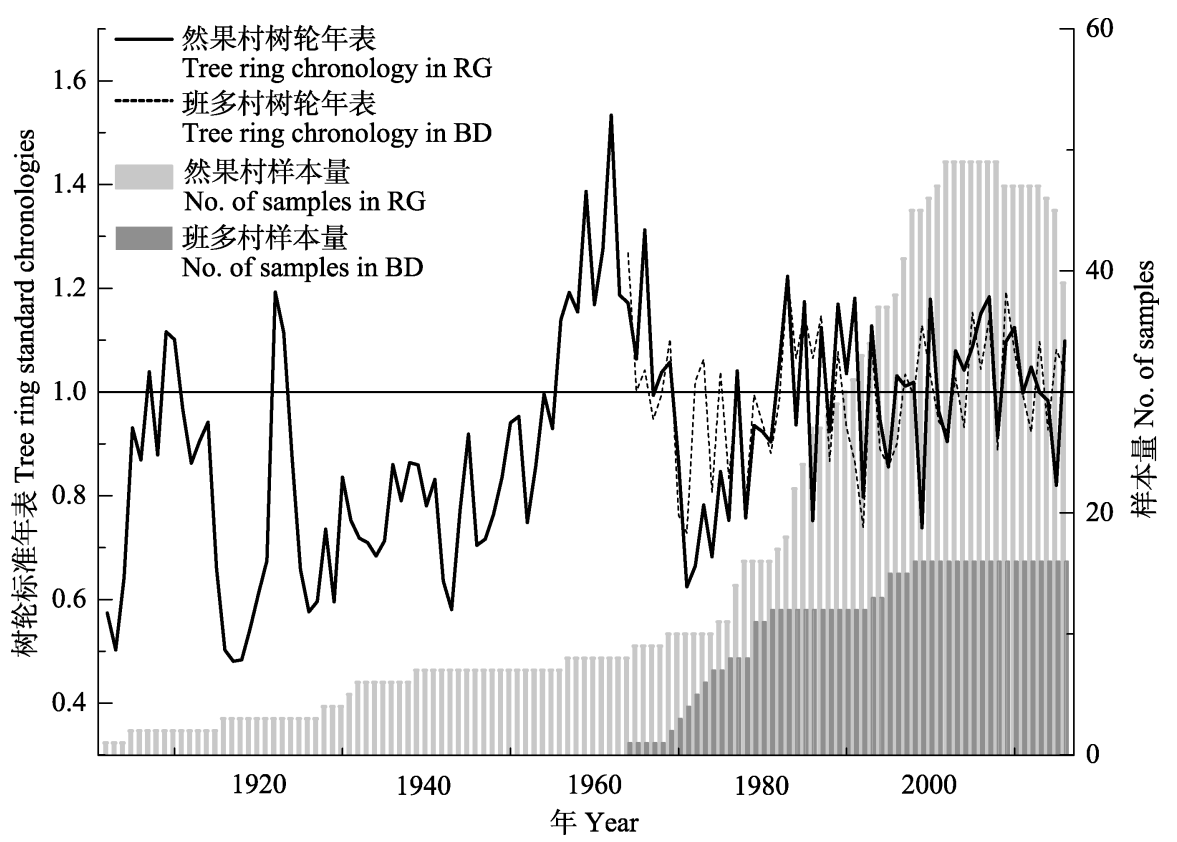

图2 甘蒙柽柳树轮标准年表。BD, 班多村; RG, 然果村。

Fig. 2 Tree ring standard chronologies of Tamarix austromongolicas. BD, Banduo Village; RG, Ranguo Village. www.plant-ecology.com 

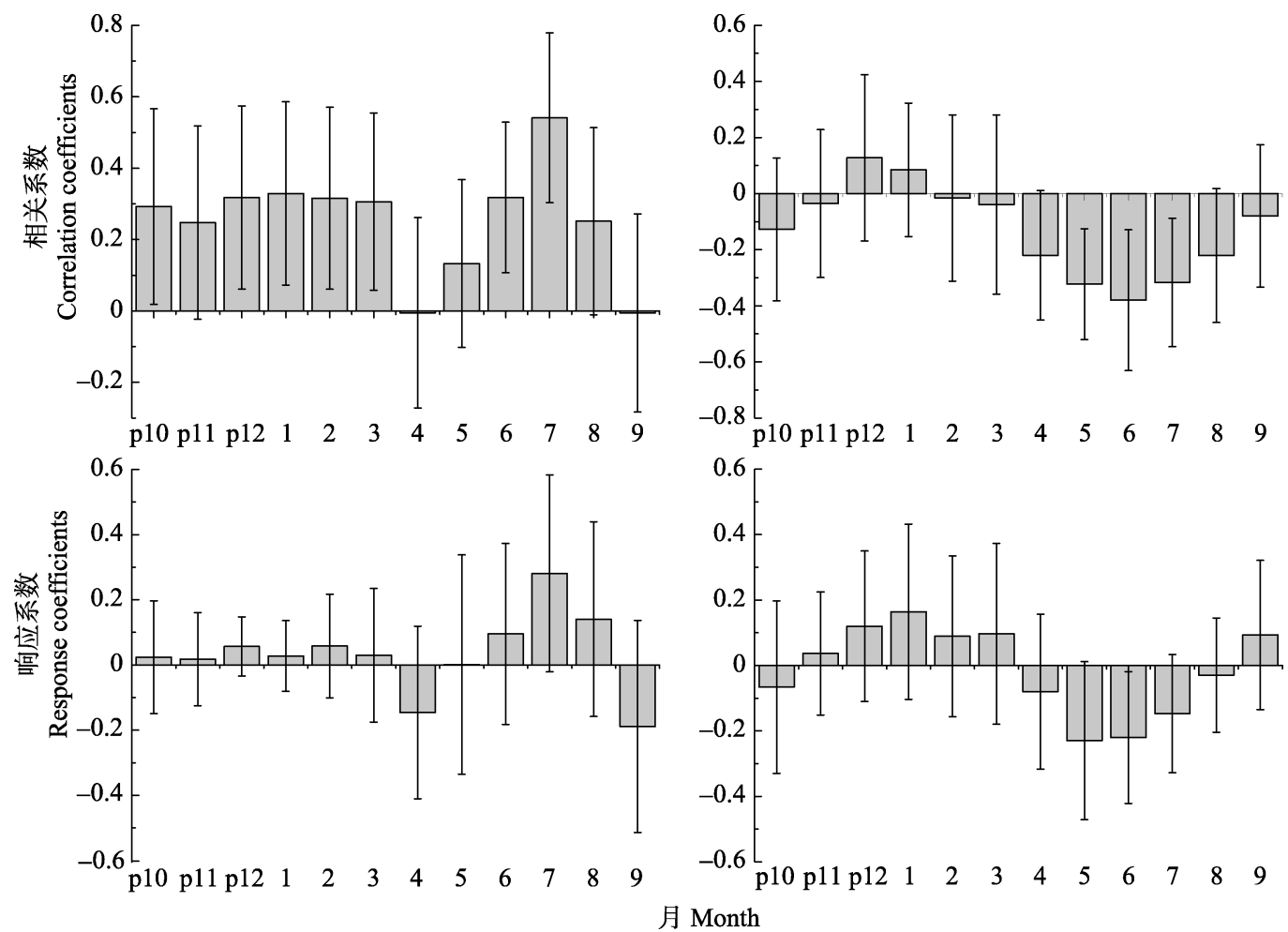

图3 班多村甘蒙柽柳生长与径流量及风速的相关及响应。左侧为甘蒙柽柳径向生长与逐月径流流量的相关及响应, 右侧为 径向生长与月平均风速的相关及响应。横坐标p表示前一年的月份, 误差条表示 $95 \%$ 置信区间。

Fig. 3 Correlation and response relationship of Tamarix austromongolica growth to monthly runoff and wind in Banduo Village. Left for the relationship between growth and runoff; Right for the relationship between growth and wind. $p$ in the abscissa indicates the month of the previous year, and the error bars show the 95\% confidence intervals.
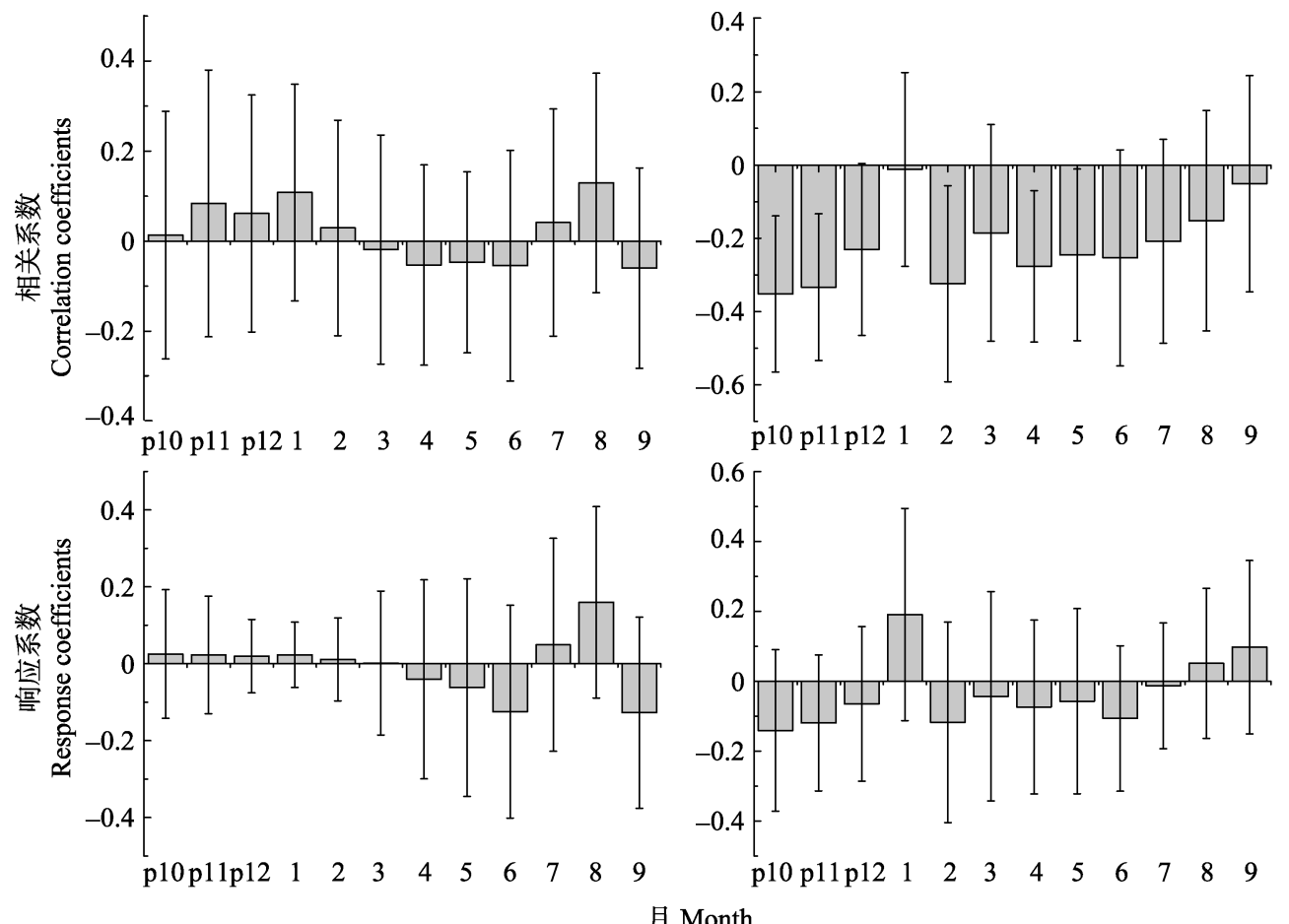

图4 然果村甘蒙柽柳生长与径流量及风速的相关及响应。左侧为甘蒙柽柳径向生长与逐月径流流量的相关及响应, 右侧为径向 生长与月平均风速的相关及响应。横坐标p表示前一年的月份, 误差条表示 $95 \%$ 置信区间。

Fig. 4 Correlation and response relationship of Tamarix austromongolica growth to monthly runoff and wind in Ranguo Village. Left for the relationship between growth and runoff; Right for the relationship between growth and wind. $\mathrm{p}$ in the abscissa indicates the month of the previous year, and the error bars show the $95 \%$ confidence intervals. 
负相关关系发生在生长季早期或是生长季前, 同时 响应分析结果表明, 径向生长与各月平均风速主成 分向量的回归函数并没有达到 $95 \%$ 显著性水平, 然 果村甘蒙柽柳径向生长对月平均风速不存在显著的 响应过程(图4)。

主要研究区年表与环境因子的滑动相关的结 果表明, 甘蒙柽柳生长与环境因子的相关关系在时 间尺度上存在较为剧烈的变化。近 50 年, 该流域径 流7月径流量与然果村甘蒙柽柳生长的相关性逐渐 减弱, 与此同步, 8月份径流流量与甘蒙柽柳生长的 相关逐渐增强(图5)。

然果村甘蒙柽柳生长与多个月份的月平均风 速的负相关在近 50 年来显著减弱, 且在近年来出现 反向特征。强风对生长季甘蒙柽柳生长的不利影响 逐渐减弱(图6)。

唐乃亥水文站记录在1971年、1988年，2001年
及2002年，7-8月黄河径流总量出现极低值(低于 $4.0 \times 10^{9} \mathrm{~m}^{3}$ ), 远小于1956-2007年7-8月黄河径流 的平均值 $\left(6.27 \times 10^{9} \mathrm{~m}^{3}\right)$ 。同期两地树轮指数平均 值分别为 $0.71 、 0.91 、 0.93$ 和 0.89 , 均为低生长年。

\section{3 讨论}

\section{1 研究区乔木状甘蒙柽柳的最大年龄估计及多} 株合生现象

早期, 有研究者(Brotherson et al., 1984; Haigh, 1998)曾对柽柳属植被的年龄-胸径关系进行了探究, 初步建立了年龄-胸径关系方程, 认为在一定范围 内随着年龄的增长, 柽柳胸径呈现线性增加趋势。 然而, 我们在对研究区乔木状甘蒙柽柳的调查中发 现，树龄确切超过百年的甘蒙柽柳一株(倒木), 疑 似超过百年的甘蒙柽柳一株, 早期人们对该地区甘 蒙柽柳年龄的直观判断存在高估。两株甘蒙柽柳均

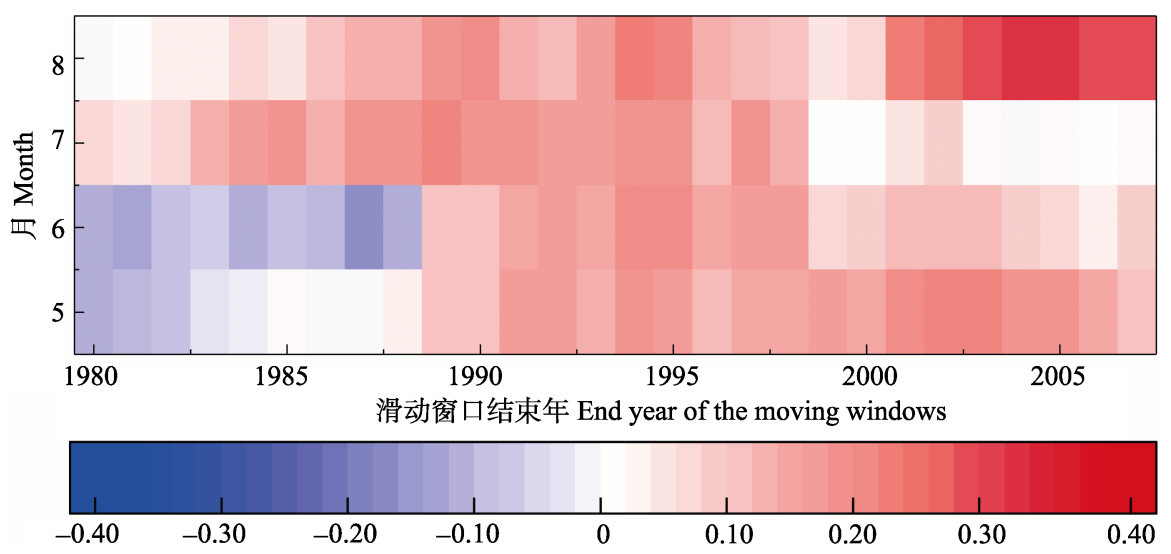

图5 然果村甘蒙柽柳生长与径流流量的滑动相关。不同颜色所对应的数值表示不同的相关系数。

Fig. 5 Moving correlation between Tamarix austromongolica growth and monthly runoff. The values represented by the different colors show the different correlation coefficients.

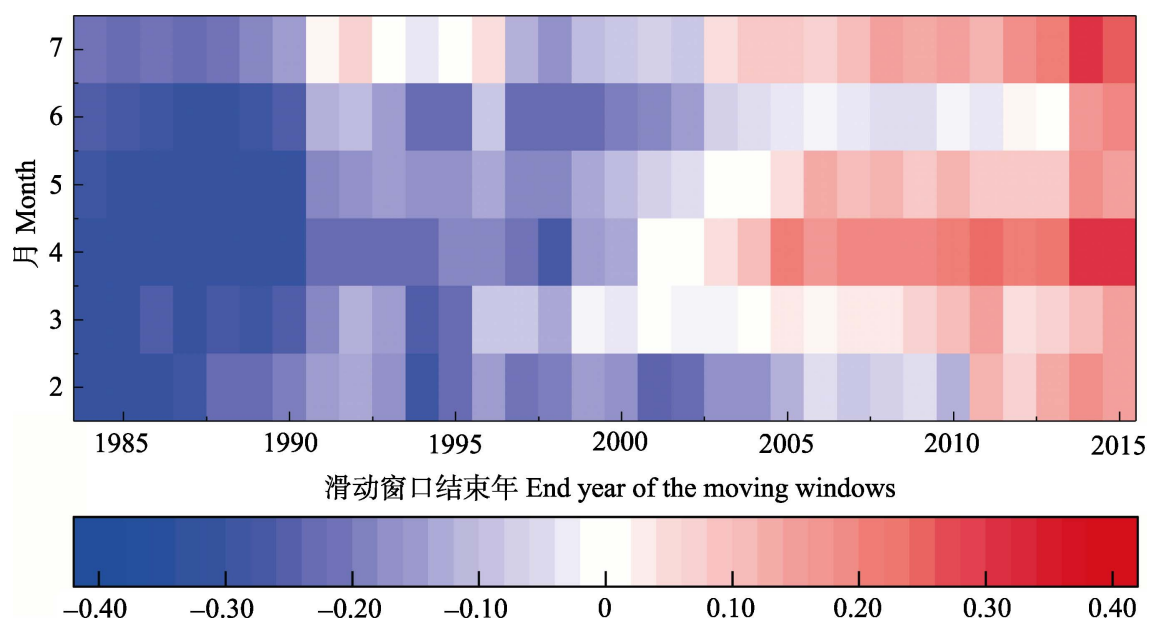

图6 然果村甘蒙柽柳与风速的滑动相关。不同颜色所对应的数值表示不同的相关系数。

Fig. 6 Moving correlation between Tamarix austromongolica growth and monthly wind speed. The values represented by the different colors show the different correlation coefficients. 
位于然果村，相对于班多村林区，然果村甘蒙柽柳 平均年龄(仅包含采样样本)较大, 存在较多年龄 $>50$ 年的植株。

柽柳属植物干形复杂, 多数研究着重于其幼体 的生长发育, 而对成年个体年龄研究较少。本研究 所涉及的甘蒙柽柳个体胸径较大, 年龄相对偏大, 与传统柽柳研究中的研究对象存在区别, 具有其独 特之处。

最为典型的独特之处在于其多株合生现象的 存在。多株合生现象在羊曲水电站库区及周边地区 甘蒙柽柳林中十分普遍, 从而使得作为灌木或者小 乔木的甘蒙柽柳能够具有高大乔木的外形特征。我 们发现，组成多株合生树的个体具有不同的年龄, 因此，多株合生树的形成是由于不同时期生长出的 植株由于分布的聚集, 在径向生长过程中逐渐发生 挤压合生在一起。在研究区, 泥石流灾害频发, 日平 均风速大, 成年植株通常具有较为明显的损伤。我 们认为, 生长在成年植株周围或甚至生长在成年植 株损伤而产生的空洞或裂隙中的幼苗可能更易在 恶劣的环境中存活, 从而促使了多株合生现象的 发生。

\section{2 甘蒙柽柳的生长与生态环境因子的关系}

由于立地条件、树木健康状况等多种因素的影 响, 同一地区同一树种树木个体间的生长差异在树 木学研究中普遍存在(Bowman et al., 2013)。本研究 甘蒙柽柳林所在研究区位于高原河漫滩, 常年大风, 生存环境恶劣, 从而导致了局地微环境变动剧烈, 甘蒙柽柳个体之间的生长速率存在较大的差异。

水分对柽柳属植物分布及生长的影响是显著 的。在我国, 蒋进和高海峰(1992)对中国主要柽柳属 植物的耐旱性进行了研究, 证明了水分条件对柽柳 属植物生长的显著影响。杨维康等(2002)对新疆柽 柳属植物分布进行了较为全面的分析, 验证了水分 条件是决定该地区柽柳属植物现代地理分布的关键 环境因子。本研究的结果表明, 高原河漫滩的乔木 状甘蒙柽柳与黄河季节性径流量间存在关联, 显著 的响应关系发生在班多村甘蒙柽柳径向生长与生长 当年7月径流之间。7-8月黄河径流流量的增加对甘 蒙柽柳的生长具有积极的作用, 体现了夏季充足的 水分条件在甘蒙柽柳生长过程中的重要性。类似的, 利用树木年轮学方法, 肖生春和肖洪浪(2006)分析 了极端干旱区湖岸柽柳径向生长对水环境演变的响
应。侯佳文等(2015)分析了博斯腾湖滨多枝柽柳 (Tamarix ramosissima)生长对湖水水位的敏感性, 表明了柽柳径向生长与当年以及前一年的湖泊水位 之间存在显著的相关性。本研究中, 甘蒙柽柳径向 生长与径流之间的相关性仍然存在时间上的变化, 在然果村, 甘蒙柽柳径向生长与7月径流量正相关 性减弱的同时, 与8月径流量正相关性增强, 一定程 度上反映了甘蒙柽柳生长与径流显著相关的时间段 在近 50 年发生推迟。

据当地水文站点及文献记载(Wang et al., 2006; Gou et al., 2007), 20世纪70年代黄河自然径流量显 著较低, 与本研究所建立的甘蒙柽柳树轮宽度年表 低值年频发时期相吻合; 进一步单年分析的结果同 时表明了在黄河7-8月径流量出现低值的年份, 树 轮径向生长量较低, 一定程度上证实了水文径流与 河漫滩甘蒙柽柳生长的关系。由于水分条件的关键 作用(郭京衡等, 2014), 使得我国柽柳属植被主要分 布在干旱、半干旱地区河岸及湖滨沙地, 河流及湖 泊水文条件通常被认为是影响该地区柽柳属植物生 长的重要环境因子(侯佳文等, 2015; 朱绪超等, 2015); 同时, 沙漠腹地地区的柽柳也与水文条件有着密切 的联系, 其通常分布在古河道或旧河床地区, 地下 水位是影响柽柳生长的关键因素(袁国富等, 2012)。

柽柳是中国西北地区重要的防风阻沙植被, 在 然果村, 甘蒙柽柳林的防风效应体现明显, 本研究 发现, 研究区植被生长当年5-6月平均风速是影响 甘蒙柽柳生长的最主要的环境限制因子, 突出表现 在两地研究区甘蒙柽柳径向生长与风速的显著负相 关关系。刘国军等(2008)对塔克拉玛干沙漠中的沙 生柽柳(Tamarix taklamakanensis)的研究表明, 多风 环境中沙生柽柳的根系形态与沙漠主导风向有着密 切的关系。在本研究中, 班多村甘蒙柽柳生长显著 负响应于5-6月风速, 然果村甘蒙柽柳生长与风速 的关系较为复杂, 体现在近 50 年来负相关关系的显 著减弱甚至反向。1971年甘蒙柽柳生长出现极低值, 结合区域甘蒙柽柳调查数据后判断林龄结构, 研究 认为 20 世纪 70 年代以来存在大量新生甘蒙柽柳个 体。从而认为, 逐渐成熟的甘蒙柽柳林对强风的抵 抗性增强, 负相关性减弱。

\section{4 结论}

青海省同德县羊曲水电站库区及附近甘蒙柽 
柳林中存在极少量树龄超过百年的植株, 其较大的 胸径以及乔木状形态的形成, 主要是由于多株合生 现象的存在。该地区现存甘蒙柽柳多生于 20 世纪 70-80年代, 20 世纪80年代后, 甘蒙柽柳生长较为平 稳。甘蒙柽柳径向生长主要响应于7-8月黄河径流以 及生长季风速。7-8月径流量的增加将有利于甘蒙柽 柳生长, 但水电站库区然果村甘蒙柽柳林对径流响 应月份表现出逐渐推迟的过程。生长季的强风对未 成熟的甘蒙柽柳的生长是不利的, 随着甘蒙柽柳林 林龄的增大, 径向生长与风速的负相关性减弱。青 海省高原河漫滩乔木状甘蒙柽柳多株合生现象的发 现在植被特殊形态的研究方面具有理论意义, 其年 龄的准确判断在对其生态价值的评估方面具有实 践意义。甘蒙柽柳历史生长及其对环境、气候因子 的响应关系的明确, 为其在气候变化下或是人为改 变的环境下的生长评估提供了科学依据, 对高原干 旱区、半干旱区生态可持续发展具有建设性的科学 价值。

\section{基金项目 国家自然科学基金(31330015)。}

致谢 感谢国家林业局组织该项研究工作, 感谢青 海省林业厅的野外协助以及数据支持。非常感谢中 国科学院植物研究所张齐兵研究员对该研究工作的 大力指导, 以及植物研究所树轮实验室工作人员张 启对树轮样本的协助处理及测量。

\section{参考文献}

Babst F, Poulter B, Trouet V, Tan K, Neuwirth B, Wilson R, Carrer M, Grabner M, Tegel W, Levanic T (2013). Siteand species-specific responses of forest growth to climate across the European continent. Global Ecology and Biogeography, 22, 706-717.

Biondi F, Waikul K (2004). DENDROCLIM2002: A C++ program for statistical calibration of climate signals in treering chronologies. Computers \& Geosciences, 30, 303311.

Birken AS, Cooper DJ (2006). Processes of Tamarix invasion and floodplain development along the lower Green River, Utah. Ecological Applications, 16, 1103-1120.

Bowman DMJS, Brienen RJW, Gloor E, Phillips OL, Prior LD (2013). Detecting trends in tree growth: Not so simple. Trends in Plant Science, 18, 11-17.

Brotherson JD, Carman JG, Szyska LA (1984). Stem-diameter age relationships of Tamarix ramosissima in central Utah. Journal of Range Management, 37, 362-364.

China Weekly (2016). Life and death robbery of Qinghai an- cient Tamarix forest. http://www.fx361.com/page/2016/ 1217/400445.shtml. Cited: 2017-03-12. (in Chinese) [中国 周刊 (2016). 青海古柽柳林生死劫. http://www.fx361. com/page/2016/1217/400445.shtml. Cited: 2017-03-12.]

Fang OY, Wang Y, Shao XM (2016). The effect of climate on the net primary productivity (NPP) of Pinus koraiensis in the Changbai Mountains over the past 50 years. Trees, 30, 281-294.

Friedman JM, Vincent KR, Shafroth PB (2005). Dating floodplain sediments using tree-ring response to burial. Earth Surface Processes and Landforms, 30, 1077-1091.

Frumkin A (2009). Stable isotopes of a subfossil tamarix tree from the dead sea region, israel, and their implications for the intermediate bronze age environmental crisis. Quaternary Research, 71, 319-328.

Gao LL, Gou XH, Deng Y, Yang MX, Zhang F (2017). Assessing the influences of tree species, elevation and climate on tree-ring growth in the Qilian Mountains of northwest China. Trees, 31, 393-404.

Gou XH, Chen FH, Cook E, Jacoby G, Yang MX, Li JB (2007). Streamflow variations of the Yellow River over the past 593 years in western China reconstructed from tree rings. Water Resources Research, 43, W06434. doi: 10.1029/2006WR005705.

Gou XH, Deng Y, Gao LL, Chen FH, Cook E, Yang MX, Zhang F (2015). Millennium tree-ring reconstruction of drought variability in the eastern Qilian Mountains, northwest China. Climate Dynamics, 45, 1761-1770.

Guo JH, Zeng FJ, Li CJ, Zhang B (2014). Root architecture and ecological adaptation strategies in three shelterbelt plant species in the southern Taklimakan Desert. Chinese Journal of Plant Ecology, 38, 36-44. (in Chinese with English abstract) [郭京衡，曾凡江，李尝君，张波 (2014). 塔克 拉玛干沙漠南缘三种防护林植物根系构型及其生态适 应策略. 植物生态学报, 38, 36-44.]

Haigh SL (1998). Stem diameter-age relationships of Tamarix ramosissima on lake shore and stream sites in southern Nevada. The Southwestern Naturalist, 43, 425-429.

Holmes RL (1983). Computer-assisted quality control in treering dating and measurement. Tree-Ring Bulletin, 43, 6978.

Horton JL, Clark JL (2001). Water table decline alters growth and survival of Salix gooddingii and Tamarix chinensis seedlings. Forest Ecology and Management, 140, 239-247.

Hou JW, Haimit Y, Ye M (2015). The sensitivity of ring width of Tamarix ramosissina to lake level of the Bosten Lake. Journal of Desert Research, 35, 667-673. (in Chinese with English abstract) [侯佳文, 海米提·依米提, 叶茂 (2015). 博斯腾湖滨柽柳(Tamarix ramosissina)生长对湖水位的 敏感性. 中国沙漠, 35, 667-673.]

Jiang J, Gao HF (1992). A study on drought resistant ordination of Tamarix L. Arid Zone Research, 9(4), 41-45. (in

www.plant-ecology.com 
Chinese with English abstract) [蒋进, 高海峰 (1992). 柽 柳属植物抗旱性排序研究. 干旱区研究, 9(4), 41-45.]

Li MQ, Shao XM, Yin ZY, Xu XG (2015). Tree-ring dating of the reshui-1 tomb in Dulan County, Qinghai Province, north-west China. PLOS ONE, 10, e0133438. doi: 10.1371/journal.pone.0133438.

Li YJ, Fang KY, Cao CF, Li DW, Zhou FF, Dong ZP, Zhang Y, Gan ZF (2016). A tree-ring chronology spanning 210 years in the coastal area of southeastern China, and its relationship with climate change. Climate Research, 67, 209-220.

Lipp J, Trimborn P, Edwards T, Waisel Y, Yakir D (1996). Climatic effects on the $\delta^{18} \mathrm{O}$ and $\delta^{13} \mathrm{C}$ of cellulose in the desert tree Tamarix jordanis. Geochimica et Cosmochimica Acta, 60, 3305-3309.

Liu GJ, Zhang XM, Li XR, Wei J, Shan LS (2008). The adaptation of the Tamarix root to the windy environment. Chinese Science Bulletin, 53, 147-150. (in Chinese) [刘国军, 张希明, 李晓荣, 魏疆, 单立山 (2008). 塔克拉玛干柽 柳的根对多风环境的适应. 科学通报, 53, 147-150.]

Norton D, Palmer J, Ogden J (1987). Dendroecological studies in new zealand 1. An evaluation of tree age estimates based on increment cores. New Zealand Journal of Botany, 25, 373-383.

Qin L, Yuan YJ, Zhang RB, Wei WS, Yu SL, Fan Z, Chen F, Zhang TW, Shang HM (2016). Tree-ring response to snow cover and reconstruction of century annual maximum snow depth for northern Tianshan Mountains, China. Geochronometria, 43, 9-17.

Rohner B, Weber P, Thürig E (2016). Bridging tree rings and forest inventories: How climate effects on spruce and beech growth aggregate over time. Forest Ecology and Management, 360, 159-169.

Shao XM, Wang SZ, Xu Y, Zhu HF, Xu XG, Xiao YM (2007). A 3500-year master tree-ring dating chronology from the northeastern part of the Qaidam Basin. Quaternary Sciences, 27, 477-485. (in Chinese with English abstract) [邵 雪梅, 王树芝, 徐岩, 朱海峰, 许新国, 肖永民 (2007). 柴达木盆地东北部3500年树轮定年年表的初步建立. 第四纪研究, 27, 477-485.]

Wang H, Yang Z, Saito Y, Liu JP, Sun X (2006). Interannual and seasonal variation of the Huanghe (Yellow River) water discharge over the past 50 years: Connections to impacts from ENSO events and dams. Global and Planetary Change, 50, 212-225.

Wang XC, Zhang MH, Ji Y, Li Zongshan, Li M, Zhang YD (2017). Temperature signals in tree-ring width and divergent growth of Korean pine response to recent climate warming in northeast Asia. Trees, 31, 415-427.

Wang XM, Zhang CX, Zhang JW, Hua T, Lang LL, Zhang XY, Wang L (2010). Nebkha formation: Implications for reconstructing environmental changes over the past several centuries in the Ala Shan Plateau, China. Palaeogeography Palaeoclimatology Palaeoecology, 297, 697-706.

Wu YH (2012). I am sad for the wild Tamarix in Qinghai. http://blog.sciencenet.cn/home.php?mod=space\&uid=3899 8\&do=blog\&id=495736. Cited: 2017-03-12. (in Chinese) [吴玉虎 (2012). 我为青海野生古柽柳悲哀. http://blog.sciencenet.cn/home.php?mod=space\&uid= 38998\&do=blog\&id=495736. Cited: 2017.3 .12 .]

Xia JB, Zhao XM, Chen YP, Fang Y, Zhao ZG (2016). Responses of water and salt parameters to groundwater levels for soil columns planted with Tamarix chinensis. PLOS ONE, 11, e0145828. doi: 10.1371/journal.pone.0145828.

Xiao SC, Peng XM, Tian QY (2016). Climatic and human drivers of recent lake-level change in east Juyan Lake, China. Regional Environmental Change, 16, 1063-1073.

Xiao SC, Xiao HL (2006). Response of radial growth of lakeshore tamarisk to changes in the water environment in extreme and arid regions. Journal of Beijing Forestry University, 28(2), 39-45. (in Chinese with English abstract) [肖生春, 肖洪浪 (2006). 极端干旱区湖岸柽柳径向生 长对水环境演变的响应. 北京林业大学学报, 28(2), 39-45.]

Xiao SC, Xiao HL, Peng XM, Tian QY (2014). Intra-annual stem diameter growth of Tamarix ramosissima and association with hydroclimatic factors in the lower reaches of China's Heihe River. Journal of Arid Land, 6, 498-510.

Xiao SC, Xiao HL, Si JH, Liu FM (2005). Growth characteristics of Tamarix ramosissima in arid regions of China. Acta Botanica Boreali-Occidentalia Sinica, 25, 1012-1016. (in Chinese with English abstract) [肖生春, 肖洪浪, 司建华, 刘发民 (2005). 干旱区多枝柽柳的生长特性. 西北植物 学报, 25, 1012-1016.]

Xiao SC, Xiao HL, Zhou MS, Si JH, Zhang XY (2004). Water level change of the West Juyan Lake in the past 100 years recorded in the tree ring of the shrubs in the lake banks. Journal of Glaciology and Geocryology, 26, 557-562. (in Chinese with English abstract) [肖生春, 肖洪浪, 周茂先, 司建华, 张小由 (2004). 近百年来西居延海湖泊水位变 化的湖岸林树轮记录. 冰川冻土, 26, 557-562.]

Xinhua News Agency (2016). Wild Tamarix forest facing submerged in Tongde Qinghai, site protection or transplant? http://www.chinanews.com/sh/2016/11-09/8058287.shtml. Cited: 2017-03-01. (in Chinese) [新华社 (2016). 青海同 德野生柽柳林面临被淹没, 原址保护还是移植? http://www.chinanews.com/sh/2016/11-09/8058287.shtml. Cited: 2017-03-01.]

Yang W, Spencer RJ, Krouse HR (1996). Stable sulfur isotope hydrogeochemical studies using desert shrubs and tree rings, Death Valley, California, USA. Geochimica et Cosmochimica Acta, 60, 3015-3022.

Yang WK, Zhang DY, Yin LK, Zhang LY (2002). Distribution and cluster analysis on the similarity of the Tamarix 
communities in Xinjiang. Arid Zone Research, 19(3), 6-11. (in Chinese with English abstract) [杨维康, 张道远, 尹林 克, 张立运 (2002). 新疆柽柳属植物(Tamarix L.) 的分 布与群落相似性聚类分析. 干旱区研究, 19(3), 6-11.]

Yin Z-Y, Li MQ, Zhang Y, Shao XM (2016). Growth-climate relationships along an elevation gradient on a southeastfacing mountain slope in the semi-arid eastern Qaidam Basin, northeastern Tibetan Plateau. Trees, 30, 1095-1109.

Yuan GF, Zhang P, Xue SS, Zhuang W (2012). Change characteristics in soil water content in root zone and evidence of root hydraulic lift in Tamarix ramossissima thickets on sand dunes. Chinese Journal of Plant Ecology, 36, 1033-1042. (in Chinese with English abstract) [袁国富, 张佩, 薛沙沙, 庄伟 (2012). 沙丘多枝柽柳灌从根层土 壤含水量变化特征与根系水力提升证据. 植物生态学 报, 36, 1033-1042.]

Zhang JC, Yao T, Liu CZ, Liu SZ, Sun T, Yuan HB, Tang JN, Ding F, Li XM, Liu R (2014). Climate environmental change and stable carbon isotopes in age layers of Tamarix sand-hillocks in Kumtag Desert. Acta Ecologica Sinica, 34, 943-952. (in Chinese with English abstract) [张锦春, 姚拓, 刘长仲, 刘世增, 孙涛, 袁宏波, 唐进年, 丁峰, 李学敏, 刘瑞 (2014). 库姆塔格柽柳沙包年层稳定碳同 位素与气候环境变化. 生态学报, 34, 943-952.]

Zhang QB, Evans MN, Lyu LX (2015). Moisture dipole over the Tibetan Plateau during the past five and a half centuries. Nature Communications, 6, 8062.

Zhu XC, Yuan GF, Shao MA, Yi XB, Du T (2015). Spatial pattern of riparian vegetation in desert of the lower Tarim River Basin. Chinese Journal of Plant Ecology, 39, 10531061. (in Chinese with English abstract) [朱绪超, 袁国富, 郡明安, 易小波, 杜涛 (2015). 塔里木河下游河岸带植 被的空间结构特征. 植物生态学报, 39, 1053-1061.]

责任编委: 郝占庆 责任编辑: 王 葳

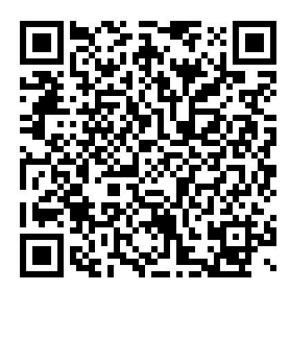

www.plant-ecology.com 